\title{
Aplikasi Manajemen Aset Dengan Penyusutan Menggunakan Metode Straight Line Pada Tv Kepri Tanjungpinang
}

\author{
Dwi Nurul Huda ${ }^{1}$, Nurul Saepul, Saiful Najib ${ }^{3}$ \\ ${ }^{1}$ dwi.nurulhuda@gmail.com \\ ${ }^{2}$ saepul@sttindonesia.ac.id \\ ${ }^{3}$ saifulnajib17@gmail.com
}

1,2,3 Sekolah Tinggi Teknologi Indonesia Tanjungpinang

Jln. Brigjen Katamso No. 92 Tanjungpinang Kepulauan Riau Indonesia

\begin{abstract}
Intisari-TV Kepri merupakan instansi yang bergerak dalam bidang pertelevisian dan penyiaran audio visual. Dalam hal ini dapat lipastikan TV Kepri memiliki aset yang banyak. Manajemen Aset pada TV Kepri sampai saat ini masih belum dimiliki, sehingga pendataan aset, peminjaman dan pelaporan penyusutan masih dilakukan secara manual. Hal ini dapat diantisipasi dengan penggunaan aplikasi dan perhitungan penyusutan aset dengan metode garis lurus (Straight Line Methode). Oleh karena itu dibutuhkan sistem informasi yang dapat membantu dalam pengelolaan aset perusahaan. Aplikasi ini dapat membantu dalam manajemen aset, pelaporan aset tahunan, terpantaunya nilai aset, pendataan manajemen aset lebih terdata serta peminjaman dan senyusutan aset terkelola dan terkontrol.
\end{abstract}

Kata Kunci : Aplikasi, Aset, TV Kepri Aset, Penyusutan, Garis Lurus

4bstract - Kepri TV is an agency engaged in television and audio-visual broadcasting. In this case, Kepri TV has many assets. Asset Management at Kepri $T V$ is still not owned, so that asset data collection, borrowing and depreciation reporting are still done manually. This can be anticipated by using applications and calculating depreciation of assets using the Straight Line Method. Therefore we need in information system that can assist in the management of company assets. This application can assist in asset management, annual zsset reporting, asset value monitoring, more recorded asset management data collection and managed and controlled asset borrowing ind depreciation.

Keywords: Applications, Assets, Depreciation, TV Kepri, Straight Line

\section{Pendahuluan}

\section{Latar Belakang}

TVKEPRI adalah sebuah instansi yang bergerak dalam bidang sertelevisian dan penyiaran audio visual. Dalam hal ini dapat lipastikan TVKEPRI memiliki aset yang banyak. Tiap aset memiliki Imur dan cara perawatan yang berbeda-beda. Beberapa sermasalahan yang terjadi pada pengelolaan aset diantaranya adalah nventaris yang belum jelas, belum adanya prosedur/SOP (Standard Jperating Procedure) penggunaan atau pemakaian aset dan belum ıdanya sistem informasi yang dapat mengelola seluruh aset yang ida.

Pengadaan aset baru pada suatu perusahaan dapat terjadi sarena berbagai hal. Misal kondisi aset yang sudah tidak layak, Imur aset yang sudah lama atau sudah kadaluarsa, atau mungkin sset yang diperlukan memang belum ada. Hal-hal yang diperlukan Jalam proses pengadaan aset antara lain prosedur pengadaan/SOP Standard Operating Procedure) dan sistm informasi. Jika kedua hal ni tidak ada maka proses pengadaan aset dapat terhambat.

Saat ini TVKEPRI belum memiliki manajemen asset, sehingga al ini dapat menghambat proses pengadaan aset, ini disebabkan sarena jika tidak ada sebuah sistem yang menginformasikan apakah sengajuan itu sudah di setujui atau belum, pihak pemohon tidak tahu Jan apabila ada barang yang rusak atau hilang akan sulit untuk liketahui siapa yang bertanggung jawab atas barang tersebut.

\section{Identifikasi Masalah}

Adapun beberapa identifikasi masalah yang terjadi pada TVKEPRI Tanjungpinang berhubungan dengan manajemen aset tdalah :
1. Pendataan aset pada TVKEPRI Tanjungpinang masih dilakukan secara manual

2. Tidak terkontrolnya pemakaian dan peminjaman barang

3. Sulitnya mencari barang saat dibutuhkan

4. Memakan banyak waktu saat diminta membuat laporan

5. Tidak mengetahui masa pemakaian dan penyusutan aset

C. Tujuan Penelitian

Tujuan dari penelitian ini adalah :

1. Membantu proses pengelolaan aset

2. Menyediakan sistem digital berhubungan dengan pengelolaan aset

3. Untuk mencapai efektivitas dan efisiensi dalam pengelolaan asset baik biaya maupun waktu

D. Kajian Pustaka

1. Definisi Aplikasi

Aplikasi adalah alat terapan yang difungsikan secara khusus dan terpadu sesuai kemapuan yang dimilikinya. Aplikasi biasanya dibentuk kedalam suatu sistem komputer yang dapat membantu kinerja pengguna untuk membantu pekerjaan dengan tujuan dapat membuat waktu lebih efisien dan efektif.

2. Aset

Aset adalah barang (thing) atau sesuatu barang (anything) yang mempunyai nilai ekonomi (economic value), nilai komersil (commercial value) atau nilai tukar (exchange value) yang dimiliki oleh badan usaha, instansi atau individu". [1] Ada dua jenis aset yaitu aset berwujud (tangible) dan aset tidak berwujud (intangible). 
Pengertian Aset negara adalah bagian dari kekayaan negara atau harta kekayaan negara (HKN) yang terdiri dari barang bergerak atau barang tidak bergerak yang dimiliki, dikuasai oleh Instansi Pemerintah, yang sebagian atau seluruhnya dibeli atas beban Anggaran Pendapatan dan Belanja Negara (APBN) serta dari perolehan yang sah, tidak termasuk kekayaan negara yang dipisahkan (dikelola BUMN) dan kekayaan Pemerintah Daerah.

Dalam pengertian hokum aset (asset) merupakan benda yang terdiri dari benda bergerak dan tidak bergerak, baik yang berwujud (tangible) maupun yang tidak berwujud (intangible) yang tercakup dalam aktiva/kekayaan atau harta kekayaan dari suatu instansi, organisasi, badan usaha atau individu.

Dalam Peraturan Pemerintah Nomor 24 tahun 2005, tentang Standar Akuntansi Pemerintah menyatakan bahwa: Aset adalah sumber daya ekonomi yang dikuasai dan/atau dimiliki oleh pemerintah sebagai akibat dari peristiwa masa lalu dan dari mana manfaat ekonomi dan/atau sosial dimasa depan diharapkan dapat diperoleh, baik oleh pemerintah maupun masyarakat, serta dapat diukur dengan satuan uang, termasuk sumber daya non keuangan yang diperlukan untuk penyediaan jasa bagi masyarakat umum dan sumber-sumber daya yang dipelihara karena alasan sejarah dan budaya.

\section{Penyusutan}

Setiap aset yang digunakan oleh perusahaan tidak dapat digunakan secara terus menerus sebab akan mengalami penurunan nilai, hal ini menyebabkan masa manfaat dan nilai guna aset semakin berkurang dari waktu kewaktu. Hal inilah yang menyebabkan adanya penyusutan pada setiap aset tetap kecuali tanah.

Penyusutan dalam akuntansi adalah alokasi sistematis jumlah yang dapat disusutkan dari suatu aset selama umur manfaatnya. Penerapan depresiasi akan memengaruhi laporan keuangan, termasuk penghasilan kena pajak suatu perusahaan. Metode yang paling mudah dan paling sering digunakan untuk menghitung penyusutan adalah metode penyusutan garis lurus (straight-line depreciation). Tapi selain itu, ada pula metode penghitungan lain yang bisa juga digunakan, seperti metode penyusutan dipercepat, penyusutan jumlah angka tahun, dan saldo menurun ganda.

Menurut Ikatan Akuntan Indonesia, ada beberapa fakta yang dapat mempengaruhi perhitungan penyusutan aset tetap selama periode berjalan, yaitu sebagai berikut :

1. Biaya perolehan

Biaya perolehan adalah biaya keseluruhan uang yang dikeluarkan untuk memperoleh suatu aset sampai siap digunakan oleh perusahaan.

2. Nilai sisa (residu)

Nilai sisa (residu) adalah taksiran harga jual ast tetap tersebut pada akhir masa manfaat aset tetap tersebut.

3. Taksiran manfaat ekonomi

Taksitan manfaat ekonomi adalah taksiran manfaat dari aset tetap tersebut. Masa manfaat adalah taksiran manfaat dari aset tersebut, bukan umur teknis.

Menurut Ikatan Akuntan Indonesia dalam Standar Akuntansi Keuangan biaya perolehan ialah jumlah kas atau setara kas yang dibayarkan atau nilai wajar dari imbalan lain yang diserahkan untuk memperoleh suatu aset pada saat perolehan atau konstruksi, atau jika dapat diterapkan, jumlah yang diatribusikan pada aset ketika pertama kali diakui sesuai dengan persyaratan tertentu.

Pemilihan metode untuk menghitung penyusutan atas aset tetap juga memiliki peranan yang sangat penting, hal ini pula dijelaskan oleh Ikatan Akuntansi Indonesia dalam Standar Akuntansi Keuangan (SAK), pemilihan metode penyusutan dan estimasi umur manfaat aset adalah hal yang memerlukan pertimbangan. Oleh karena itu, pengungkapan metode yang digunakan dan estimasi umur manfaat atau tariff penyusutan menyediakan informasi bagi pengguna laporan keuangan dalam mengkaji kebijakan yang dipilih manajemen dan memungkinkan perbandingan dengan entitas lain. Untuk alas an yang serupa, juga diungkapkan “

a. Penyusutan, apakah diakui dalam laba rugi atau diakui sebagai baigan dari biaya perolehan aset lain, selama satu periode, dan

b. Akumulasi penyusutan pada akhir periode.

Terdapat beberapa metode untuk mengalokasikan biaya perolehan aset tetap kedalam periode aset tetap tersebut diantaranya dijelaskan menurut Ikatan Akuntan Indonesia :

1. Metode garis lurus (straight line method)

Adalah suatu metode perhitungan penyusutan aset tetap dan setiap periode akuntansi diberikan beban yang sama secara merata. Formula metode garis lurus ialah sebagai berikut :

\section{Biaya perolehan - Nilai sisa \\ Penyusutan $=$ Taksiran manfaat ekonomi}

Atau menggunakan perhitungan ini bila pada akhir masa manfaat ekonomi aset tidak dijual dan dihentikan pemakaiannya :

\section{Penyusutan $=$ Taksiran manfaat ekonomi}

Dapat pula dihitung dengan persentase sebagai berikut :

$$
\begin{aligned}
& \text { Penyusutan }=\frac{100 \% \text { Tarif }}{\text { Taksiran manfaat ekonomi }} \\
& \text { Penyusutan }=\text { Tarif } x \text { Biaya Perolehan }
\end{aligned}
$$

2. Metode saldo menurun (diminishing balance method) Beban penyusutan makin menurun dari tahun ke tahun. Pembebanan yang makin turun didasarkan pada anggapan bahwa semakin tua, kapasitas aset dalam memberikan jasanya akan semakin menurun juga. Formula untuk saldo menurun ialah sebagai berikut :

Penyusutan $=$ Tarif penyusutan $x$ Dasar Penyusutan Dasar Penyusutan = Nilai Buku Awal

3. Metode jumlah unit produksi (sum of the unit of production method)

Adalah suatu metode perhitungan penyusutan aset tetap, beban penyusutan pada suatu periode akuntansi dihitung tersebut dengan mempergunakan aset tetap tersebut. Formula untuk menghitung metode jumlah unit produksi ialah :

\section{(Biaya perolehan-Nilai sisa )xJam Penggunaan Penyu $=$ Taksiran jumlah total produk yang dihasilkan}

Menurut Peraturan Menteri Keuangan Nomor 96/PMK.03/2009 Tentang jenis-jenis harta yang termasuk dalam kelompok harta berwujud bukan bangunan untuk keperluan penyusutan, terlampir daftar jenis-jenis harta berwujud yang termasuk dalam kelompok satu yaitu :

Tabel 2.1 Jenis-Jenis Harta Berwujud Yang Termasuk Dalam Kelompok Satu

\begin{tabular}{|l|ll|ll|}
\hline No & \multicolumn{2}{|c|}{ Jenis Usaha } & \multicolumn{2}{c|}{ Jenis Harta } \\
\hline 1 & $\begin{array}{l}\text { Semua Jenis } \\
\text { Usaha }\end{array}$ & $\begin{array}{l}\text { Mebel dan peralatan dari kayu } \\
\text { atau rotan termasuk meja, }\end{array}$ \\
\hline
\end{tabular}




\begin{tabular}{|c|c|c|}
\hline & & \begin{tabular}{|ll} 
& bangku,kursi lemari dan \\
sejenisnya yang bukan bagia \\
dari bangunan \\
b.
\end{tabular} \\
\hline 2 & $\begin{array}{l}\text { Pertanian, } \\
\text { perkebunan, } \\
\text { kehutanan } \\
\text { peternakan, } \\
\text { perikanan }\end{array}$ & $\begin{array}{l}\text { Alat yang digerakkan bukan } \\
\text { dengan mesin seperti cangkul, } \\
\text { peternakan, perikanan, garu dan } \\
\text { lain-lain. }\end{array}$ \\
\hline 3 & $\begin{array}{l}\text { Industri } \\
\text { makanan dan } \\
\text { minuman }\end{array}$ & $\begin{array}{l}\text { Mesin ringan yang dapat } \\
\text { dipindah-pindahkan seperti, } \\
\text { huller, pemecah kulit, penyosoh, } \\
\text { pengering, pallet, dan sejenisnya. }\end{array}$ \\
\hline 4 & $\begin{array}{l}\text { Transportasi } \\
\text { dan } \\
\text { pergudangan }\end{array}$ & $\begin{array}{l}\begin{array}{l}\text { Mobil taksi, bus dan truk yang } \\
\text { digunakan sebagai angkutan } \\
\text { umum. }\end{array} \\
\end{array}$ \\
\hline 5 & $\begin{array}{l}\text { Industri Semi } \\
\text { Konduktor }\end{array}$ & $\begin{array}{l}\text { Falsh memory tester, writer } \\
\text { machine, biporar test system, } \\
\text { elimination (PE8-1), pose checker. }\end{array}$ \\
\hline 6 & $\begin{array}{l}\text { Jasa } \\
\text { Persewaan } \\
\text { Peralatan } \\
\text { Tambat Air } \\
\text { Dalam } \\
\end{array}$ & $\begin{array}{l}\text { Anchor, Anchor Chains, Polyester } \\
\text { Rope, Steel Buoys, Steel Wire } \\
\text { Ropes, Mooring Accessoris. }\end{array}$ \\
\hline 7 & $\begin{array}{l}\text { Jasa } \\
\text { telekomunikasi }\end{array}$ & Base Station Controller \\
\hline
\end{tabular}

Tabel 2.2 Jenis-Jenis Harta Berwujud Yang Termasuk Dalam Kelompok Dua

\begin{tabular}{|c|c|c|}
\hline No & Jenis Usaha & Jenis Harta \\
\hline 1 & $\begin{array}{l}\text { Semua } \\
\text { Usaha }\end{array}$ & $\begin{array}{ll}\text { a. Mebel dan peralatan dari } \\
\text { logam termasuk meja, } \\
\text { bangku, kursi, lemari dan } \\
\text { sejenisnya yang bukan } \\
\text { merupakan bagian dari } \\
\text { bangunan. Alat pengatur } \\
\text { udara seperti AC, kipas angin } \\
\text { dan sejenisnya. } \\
\text { b. Mobil, bus, truk speed boat } \\
\text { dan sejenisnya. } \\
\text { c. Container dan sejenisnya. }\end{array}$ \\
\hline 2 & $\begin{array}{l}\text { Pertanian, } \\
\text { perkebunan, } \\
\text { peternakan, } \\
\text { perikanan }\end{array}$ & $\begin{array}{ll}\text { a. } & \text { Mesin pertanian } \\
\text { perkebunan seperti traktor } \\
\text { dan mesin bajak, penggaruk, } \\
\text { penanaman, penebar benih } \\
\text { dan sejenisnya }\end{array}$ \\
\hline
\end{tabular}

\begin{tabular}{|c|c|c|}
\hline & & $\begin{array}{l}\text { b. Mesin yang mengolah atau } \\
\text { menghasilkan an atau } \\
\text { memproduksi bahan atau } \\
\text { barang pertanian, } \\
\text { perkebunan, peternakan dan } \\
\text { perikanan. }\end{array}$ \\
\hline 3 & $\begin{array}{l}\text { Industri } \\
\text { makanan dan } \\
\text { minuman }\end{array}$ & 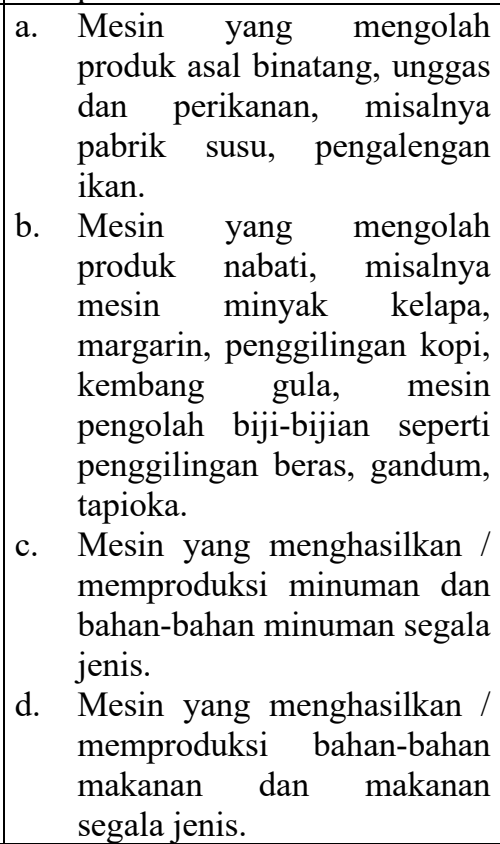 \\
\hline 4 & Industri mesin & $\begin{array}{l}\text { Mesin yang menghasilkan / } \\
\text { memproduksi mesin ringan } \\
\text { (misalnya mesin jahit, pompa } \\
\text { air). }\end{array}$ \\
\hline 5 & $\begin{array}{l}\text { Perkayuan, } \\
\text { kehutanan }\end{array}$ & $\begin{array}{lll}\text { a. } & \text { Mesin dan peralatan } \\
& \text { penebangan kayu. } \\
\text { b. } & \text { Mesin yang mengolah atau } \\
& \text { menghasilkan } & \text { atau } \\
& \text { memproduksi bahan atau } \\
& \text { barang kehutanan. } & \\
\end{array}$ \\
\hline 6 & Konstruksi & $\begin{array}{l}\text { Peralatan yang dipergunakan } \\
\text { seperti truk berat, dump truck, } \\
\text { crane buldozer dan sejenisnya }\end{array}$ \\
\hline 7 & $\begin{array}{l}\text { Transportasi } \\
\text { dan } \\
\text { Pergudangan }\end{array}$ & \begin{tabular}{|ll} 
a. & Truk kerja untuk \\
pengangkutan dan bongkar \\
muat, truk peron, truck \\
ngangkang, dan sejenisnya; \\
b. Kapal penumpang, kapal \\
barang, kapal khusus dibuat \\
untuk pengangkutan barang \\
tertentu (misalnya gandum, \\
batu - batuan, biji tambang \\
dan sebagainya) termasuk \\
kapal pendingin, kapal \\
tangki, kapal penangkap ikan \\
dan sejenisnya, yang \\
mempunyai berat sampai \\
dengan 100 DWT; \\
c. Kapal yang dibuat khusus \\
untuk menghela atau \\
mendorong kapal-kapal suar, \\
kapal pemadam kebakaran, \\
kapal keruk, keran \\
d. Perahu layar pakai atau tanpa \\
motor yang mempunyai berat \\
sampai dengan 250 DWT; \\
e. Kapal balon.
\end{tabular} \\
\hline
\end{tabular}




\begin{tabular}{|c|c|c|}
\hline 8 & Telekomunikasi & $\begin{array}{ll}\text { a. } & \text { Perangkat pesawat telepon; } \\
\text { b. } & \text { Pesawat telegraf termasuk } \\
& \text { pesawat pengiriman dan } \\
\text { penerimaan radio telegraf dan } \\
\text { radio telepon. }\end{array}$ \\
\hline 9 & $\begin{array}{l}\text { Industri semi } \\
\text { konduktor }\end{array}$ & $\begin{array}{l}\text { Auto frame loader, automatic } \\
\text { logic handler, baking oven, ball } \\
\text { shear tester, bipolar test handler } \\
\text { (automatic), cleaning machine, } \\
\text { coating } \\
\text { machine, curing oven, cutting } \\
\text { press, dambar cut machine, } \\
\text { dicer, die bonder, die shear test, } \\
\text { dynamic burn-in system oven, } \\
\text { dynamic test } \\
\text { handler, eliminator (PGE-01), } \\
\text { full automatic handler, full } \\
\text { automatic mark, hand maker, } \\
\text { individual mark, inserter } \\
\text { remover machine, laser } \\
\text { marker (FUM A-O1), logic test } \\
\text { system, marker (mark), memory } \\
\text { test system, molding, mounter, } \\
\text { MPS automatic, MPS manual, } \\
\text { O/S tester } \\
\text { manual, pass oven, pose checker, } \\
\text { re-form machine, SMD stocker, } \\
\text { taping machine, tiebar cut press, } \\
\text { trimming/forming machine, wire } \\
\text { bonder, wire pull tester }\end{array}$ \\
\hline 10 & $\begin{array}{l}\text { Jasa Persewaan } \\
\text { peralatan } \\
\text { Tambat Air } \\
\text { Dalam } \\
\end{array}$ & $\begin{array}{l}\text { Spoolling Machines, } \\
\text { Metocean Data Collector }\end{array}$ \\
\hline 11 & $\begin{array}{l}\text { Jasa } \\
\text { Telekomunikasi } \\
\text { Selular }\end{array}$ & 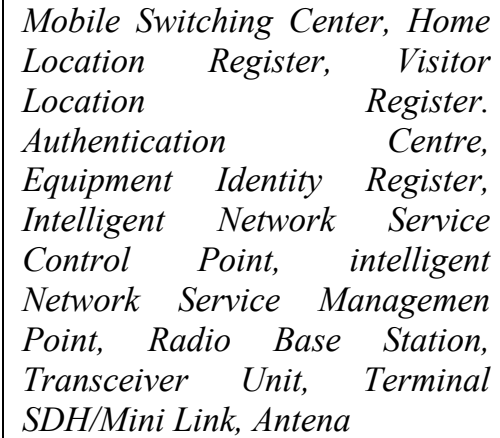 \\
\hline
\end{tabular}

Tabel 2.3 Jenis-Jenis Harta Berwujud Yang Termasuk Dalam Kelompok Tiga

\begin{tabular}{|l|l|l|}
\hline No & Jenis Usaha & Jenis Harta \\
\hline 1 & $\begin{array}{l}\text { Pertambangan } \\
\text { selain minyak }\end{array}$ & $\begin{array}{l}\text { Mesin-mesin yang dipakai dalam } \\
\text { bidang pertambangan, termasuk } \\
\text { mesin-mesin yang mengolah } \\
\text { produk pelikan }\end{array}$ \\
\hline 2 & $\begin{array}{l}\text { Permintalan, } \\
\text { pertenunan } \\
\text { dan } \\
\text { pencelupan }\end{array}$ & $\begin{array}{l}\text { a. Mesin yang } \\
\text { mengolah/menghasilkan produk- } \\
\text { produk tekstil (misalnya kain } \\
\text { katun, sutra, serat-serat buatan, } \\
\text { wol dan bulu hewan } \\
\text { lainnya, lena rami, permadani, } \\
\text { kain-kain bulu, tule). } \\
\text { b. Mesin untuk yang preparation, } \\
\text { bleaching, dyeing, printing, } \\
\text { finishing, texturing, packaging } \\
\text { dan sejenisnya. }\end{array}$ \\
\hline
\end{tabular}

\begin{tabular}{|c|c|c|}
\hline 3 & Perkayuan & $\begin{array}{l}\text { a. Mesin yang } \\
\text { mengolah/menghasilkan produk- } \\
\text { produk kayu, barang-barang dari } \\
\text { jerami, rumput dan bahan } \\
\text { anyaman lainnya. } \\
\text { b. Mesin dan peralatan } \\
\text { penggergajian kayu. }\end{array}$ \\
\hline 4 & Industri kimia & $\begin{array}{l}\text { Mesin peralatan yang } \\
\text { mengolah/menghasilkan produk } \\
\text { industri kimia dan industri yang } \\
\text { ada hubungannya dengan industri } \\
\text { kimia } \\
\text { (misalnya bahan kimia anorganis, } \\
\text { persenyawaan organis dan } \\
\text { anorganis dan logam mulia, } \\
\text { elemen radio aktif, isotop, bahan } \\
\text { kimia } \\
\text { organis, produk farmasi, pupuk, } \\
\text { obat celup, obat pewarna, cat, } \\
\text { pernis, minyak eteris dan } \\
\text { resinoida-resinonida wangi- } \\
\text { wangian, obat } \\
\text { kecantikan dan obat rias, sabun, } \\
\text { detergent dan bahan organis } \\
\text { pembersih lainnya, zat albumina, } \\
\text { perekat, bahan peledak, produk } \\
\text { pirotehnik, korek api, alloy } \\
\text { piroforis, barang fotografi dan } \\
\text { sinematografi. } \\
\text { b. Mesin yang } \\
\text { mengolah/menghasilkan produk } \\
\text { industri lainnya (misalnya damar } \\
\text { tiruan, bahan plastik, ester dan } \\
\text { eter dari selulosa, } \\
\text { karet sintetis, karet tiruan, kulit } \\
\text { samak, jangat dan kulit mentah). }\end{array}$ \\
\hline 5 & Industri mesin & $\begin{array}{l}\text { Mesin } \\
\text { menghasilkan/memproduksi } \\
\text { mesin menengah dan berat } \\
\text { (misalnya mesin mobil, mesin } \\
\text { kapal). }\end{array}$ \\
\hline 6 & $\begin{array}{l}\text { Transportasi } \\
\text { Pergudangan }\end{array}$ & \begin{tabular}{|ll} 
a. & Kapal penumpang, kapal \\
& barang, kapal khusus dibuat \\
& untuk pengangkutan barang- \\
& barang tertentu (misalnya \\
& gandum, batu-batuan, biji \\
& tambang dan sejenisnya) \\
& termasuk kapal pendingin dan \\
& kapal tangki, kapal \\
& penangkapan ikan dan \\
& sejenisnya, yang mempunyai \\
& berat di atas 100 DWT \\
& sampai dengan 1.000 DWT. \\
b. & Kapal dibuat khusus untuk \\
& mengela atau mendorong \\
& kapal, kapal suar, kapal \\
& pemadam kebakaran, kapal \\
& keruk, keran terapung dan \\
& sejenisnya, yang mempunyai \\
& berat di atas 100 DWT \\
sampai dengan 1.000 DWT. \\
c. & Dok terapung. \\
d. & Perahu layar pakai atau tanpa \\
& motor yang mempunyai berat
\end{tabular} \\
\hline
\end{tabular}




\begin{tabular}{|l|l|l|}
\hline & & \multicolumn{2}{|c|}{$\begin{array}{l}\text { di atas 250 DWT. } \\
\text { e. Pesawat terbang dan } \\
\text { helikopter-helikopter segala } \\
\text { jenis. }\end{array}$} \\
\hline 7 & $\begin{array}{l}\text { Jasa } \\
\text { Telekomunika } \\
\text { si Seluler }\end{array}$ & $\begin{array}{l}\text { Perangkat radio navigasi, radar } \\
\text { dan kendali jarak jauh }\end{array}$ \\
\hline
\end{tabular}

Tabel 2.4 Jenis-jenis Harta Berwujud Yang Termasuk Dalam Kelompok Empat

\begin{tabular}{|c|c|c|}
\hline No & Jenis Usaha & Jenis Harta \\
\hline 1 & Konstruksi & Mesin berat untuk Konstruksi \\
\hline 2 & $\begin{array}{l}\text { Transportasi } \\
\text { dan } \\
\text { Pergudangan }\end{array}$ & $\begin{array}{ll}\text { a. } & \begin{array}{l}\text { Lokomotif uap dan tender } \\
\text { atas rel. }\end{array} \\
\text { b. } & \begin{array}{l}\text { Lokomotif listrik ats rel, } \\
\text { dijalankan dengan batere atau } \\
\text { dengan tenaga listrik dari }\end{array} \\
\text { sumber luar. } \\
\text { c. } \\
\text { d. } \\
\text { Lokomotif atas rel lainnya } \\
\text { dan barang, termasuk } \\
\text { kontainer khusu dibuat dan } \\
\text { diperlengkapi untuk ditari } \\
\text { dengan satu alat atau } \\
\text { beberapa alat pengangkut. } \\
\text { e. } & \text { Kapal penumpang, kapal } \\
\text { barang, kapal khusus dibuat } \\
\text { untuk pengangkutan barang- } \\
\text { barang tertentu (misalnya } \\
\text { gandum, batu-batuan, biji } \\
\text { tambang dan sejenisnya) } \\
\text { termasuk kapal pendingin dan } \\
\text { kapal tangki, kapal perangkap } \\
\text { ikan dan sejenisnya, yang } \\
\text { mempunyai berat diatas 1.000 } \\
\text { DWT. } \\
\text { f. } \\
\text { Kapal dibuat khusus untuk } \\
\text { menghela atau mendorong } \\
\text { kapal, kapal suar, kapal } \\
\text { pemadam kebakaran, kapal } \\
\text { keruk, keran-keran terapung } \\
\text { dan sebagainya, yang } \\
\text { mempunyai berat di atas } \\
\text { 1.000 DWT. } \\
\text { g. Dok-dok terapung. }\end{array}$ \\
\hline
\end{tabular}

Dari peraturan menteri keuangan diatas, maka peralatan senyiaran TV termasuk pada kelompok satu jenis-jenis harta serwujud menurut PMK No. 09/PMK.03/2009. Jenis - jenis harta serwujud yang termasuk pada Kelompok Satu juga tercantum pada Jndang - Undang Republik Indonesia Nomor 36 Tahun 2008 Tentang Perubahan Keempat atas Undang-undang Nomor 7 Tahun 1983 Tentang Pajak Penghasilan di Pasal 11 Ayat 6 yang berbunyi ' Untuk menghitung penyusutan, masa manfaat dan tarif penyusutan larta berwujud ditetapkan sebagai berikut: “

Dari ketentuan-ketentuan diatas dapat diambil kesimpulan sahwa aset-aset penyiaran pada TVKEPRI Tanjungpinang termasuk sada Kelompok 1 dengan perkiraan masa manfaat atau masa zkonomi selama 4 tahun.

\section{Metodologi Penelitian}

Metodologi penelitian yang digunakan meliputi :
1. Metode Pengumpulan Data

Metode pengumpulan data yang digunakan dalam penelitian ini adalah sebagai berikut :

a. Observasi

Melakukan observasi/Peninjauan tempat sebelum pelaksanaan kegiatan pengumpulan data dengan mengadakan pengenalan terhadap objek, aktivitas kerja dan bahan kajian.

b. Wawancara

Melakukan wawancara secara langsung dengan pihakpihak yang terlibat dalam sistem.

c. Studi Kepustakaan

Melakukan pengumpulan data secara tidak langsung dengan melakukan studi kepustakaan, yaitu dengan mengumpulkan data-data dan teori-teori yang berhubungan.

\section{Metode Pembangunan Perangkat Lunak}

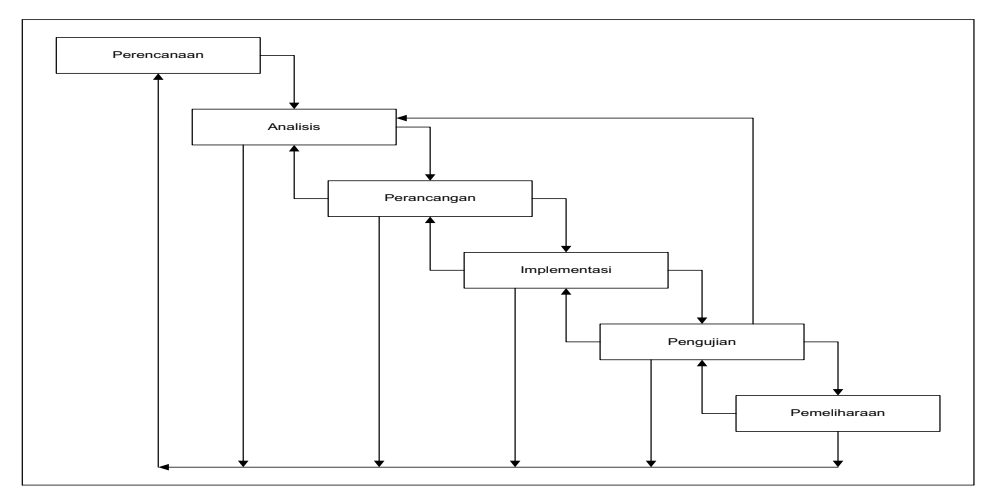

Gambar 3.1. Model Pengembangan Air Terjun

Paradigma dari tahapan model waterfall adalah sebagai berikut:

a. Perencanaan

Tahap dimana menentukan kebutuhan-kebutuhan bagi seluruh elemen-elemen sistem, kemudian mengalokasikan beberapa subset dari kebutuhan-kebutuhan tersebut bagi perangkat. Gambaran sistem merupakan hal yang penting pada saat perangkat lunak harus berinteraksi dengan elemen sistem lain seperti perangkat keras, manusia dan database. System Engineering mencakup kumpulan kebutuhan pada setiap tingkat teratas perancangan dan analisis.

b. Analisis

Tahap dimana kita menterjemahkan kebutuhan pengguna kedalam spesifikasi kebutuhan sistem atau SRS (System Requirement Spesification). Spesifikasi kebutuhan sistem ini bersifat menangkap semua yang dibutuhkan sistem dan dapat terus diperbaharui secara iterative selama berjalannya proses pengembangan sistem.

c. Perancangan

Tahap dimana dimulai dengan pernyataan masalah dan diakhiri dengan rincian perancangan yang dapat ditransformasikan ke sistem operasional. Transformasi ini 
mencakup seluruh aktivitas pengembangan perangkat lunak serta pengujiannya.

d. Implemantasi

Tahap implementasi dimana kita mengimplementasikan perancangan sistem ke situasi nyata. Disini kita mulai berurusanI denganI pemrilihran perangkat keras, penyusuman perangkat tuinak aplikasi(pengkodean/coding)).

e. Pengujian

Merepresentasikan penginstalan perangkat lunak dalam lingkungan dengan sistem operasional. Dalam hal ini, juga dilakukan penyesuaian-penyesuaian dengan sistem operasional yang sudah/akan berjalan guna memastikan perangkat lunak yang dibuat sesuai denganrapa yang diharapkan. Horraman

f. Pemeliharaantamaset

Melakukan pemeliharaan/perawatan terhadap perangkat lunak dimână dan +jika diperrukan kita melakukan perbaikan-perbaikan kecil. Kemm dilnin, jika waktu penggunaan sistem habis maka kita akan masúk lagi pada tahap perencanalahtosarans

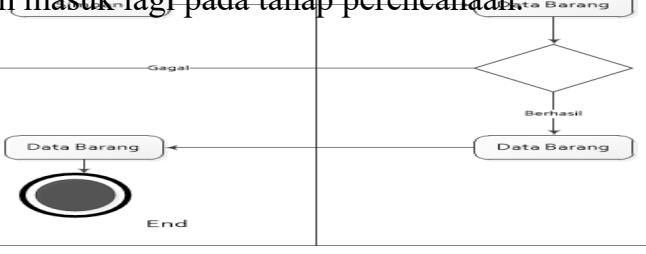

\section{HASIL DAN PEMBahasan}

4. Perhitungan Penyusunan Aset

Penyusutan metode garis lurus adalah salah satu metode yang termasuk paling banyak diaplikasikan oleh perusahaan di Indonesia. Metode garis lurus menganggap aktiva tetap akan memberikan kontribusi yang merata disepanjang masa penggunaannya, sehingga aset tetap akan mengalami tingkat penurunan fungsi yang sama dari tahun ke tahun lainya hingga aktiva tetap tersebut tidak digunakan kembali dalam kegiatan operasional perusahaan. Perhitungan penyusutan dengan metode garis lurus adalah sebagai berikut :

Penyusutan $=$ Biaya perolehan - Nilai sisa

\section{Taksiran manfaat ekonomi}

Atau menggunakan perhitungan berikut jika pada akhir masa manfaat ekonomi aset tidak dijual dan dihentikan pemakaiannya :

Penyusutan $=$

\section{Biaya perolehan}

\section{Taksiran manfaat ekonomi}

\section{Perancangan}

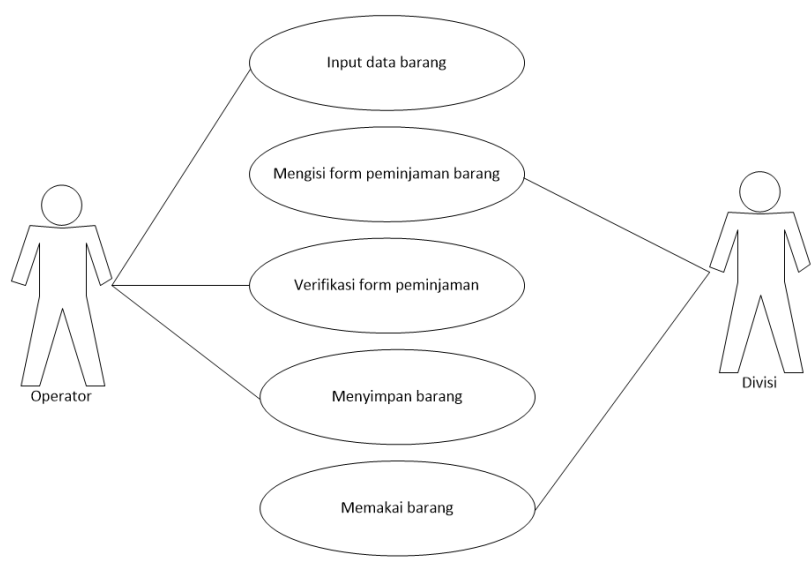

Gambar 4.1 Use Case Diagram Usulan Aplikasi Manajemen Aset TV KEPRI

Gambar 4.2 Actvity Diagram Usulan Aplikasi Manajemen Aset TV KEPRI

C. Implementasi

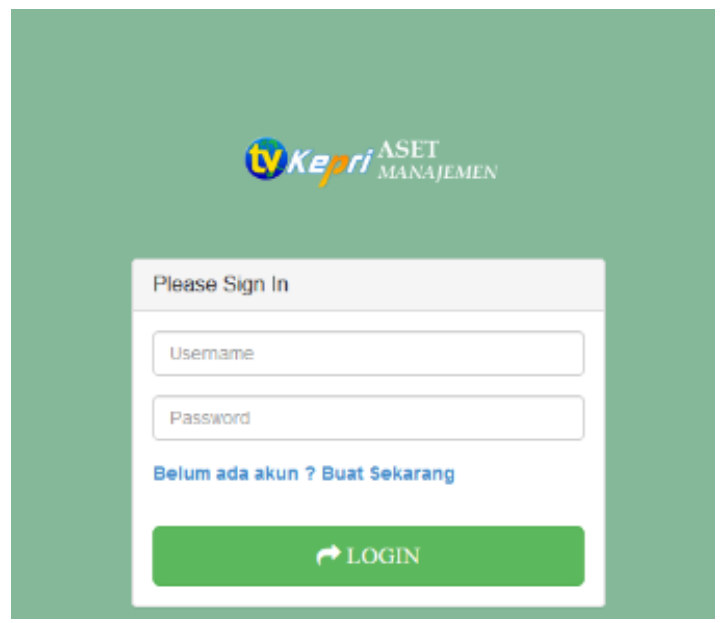

Gambar 4.3 login account

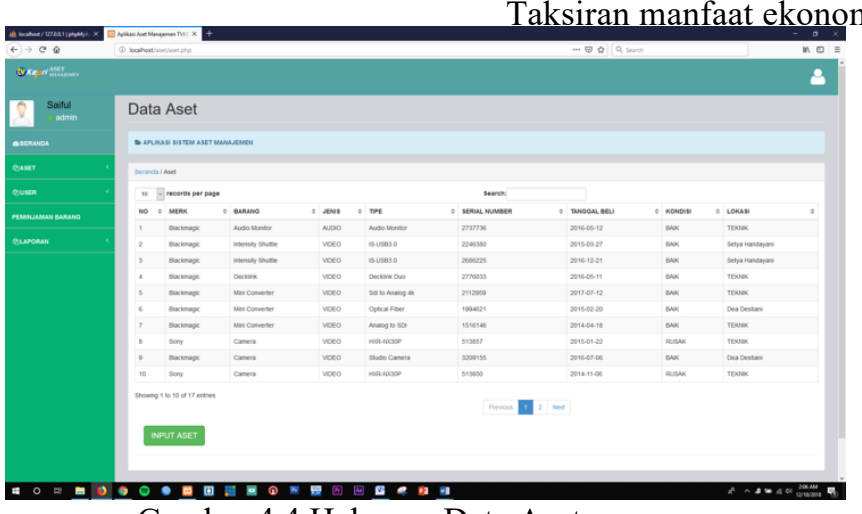

Gambar 4.4 Halaman Data Aset 


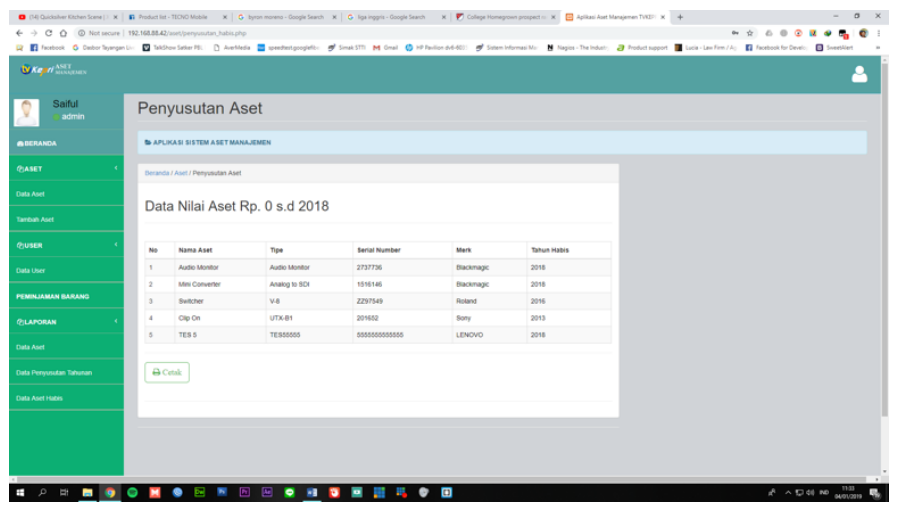

Gambar 4.5 Halaman Data Aset

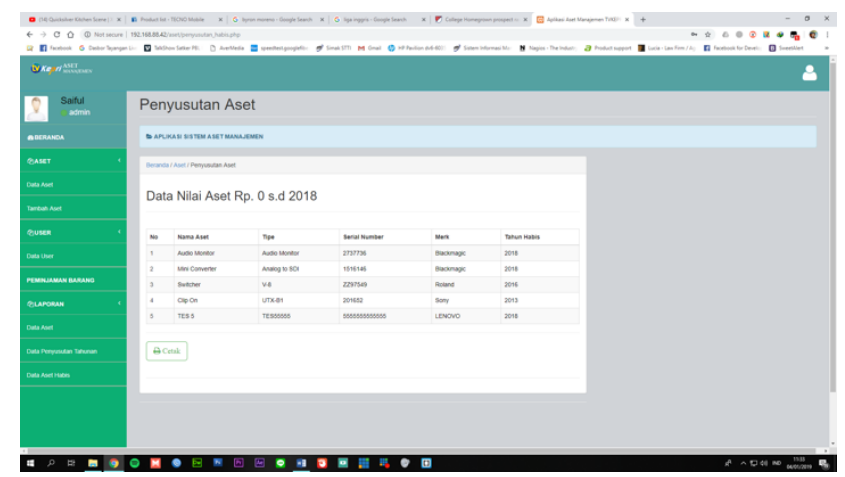

Gambar 4.6 Halaman Detail Penyusutan Aset Habis

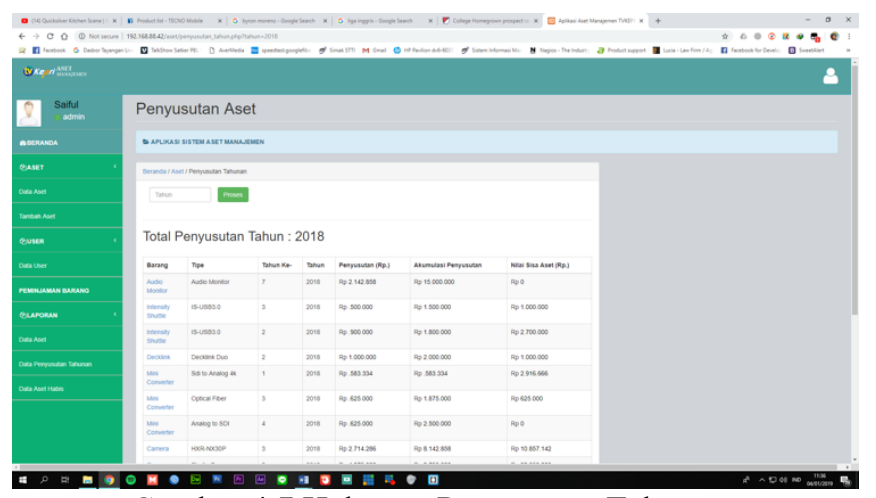

Gambar 4.7 Halaman Penyusutan Tahunan

\section{KESIMPULAN}

Berdasarkan hasil proses perancangan dan pembuatan serangkat lunak yang dibuat untuk TV KEPRI Tanjungpinang, senulis menyimpulkan bahwa :

1. Pendataan manajemen aset lebih terdata, karena dengan sistem yang baru ini, memudahkan pegawai dalam melakukan pengaduan kondisi barang.

2. Penyusutan aset menggunakan metode garis lurus (straight line) dan pelaporan penyusutan aset terkelola dan terkontrol .

\section{REFERENSI}

[1] Ikatan Akuntan Indonesia, Pernyataan Standar Akuntansi Keuangan Nomor 16 (revisi 2007), Salemba Empat, 2009, Jakarta: Salemba Empat,.

[2] Menteri Keuangan, Peraturan Menteri Keuangan No. 96/PMK.03/2009 Tentang Jenis-Jenis Harta Yang Termasuk Dalam Kelompok Harta Berwujud Bukan Bangunan untuk Keperluan Penyusutan, 2009, Jakarta.
[3] Nugroho Bunafit, Aplikasi Pemrograman Web Dinamis dan MySQL, 2008, Yogyakarta

[4] Pardiangan Liberti, Modernisasi \& Reformasi Pelayanan Perpajakan Berdasarkan UU Terbaru,2008, Jakarta : Elex Media Komputindo

[5] Undang-Undang Republik Indonesia, Nomor 36 Tahun 2008 Tentang Perubahan Keempat atas UU No. 7 Tahun 1983 Tentang Pajak Penghasilan (11:6), 2008, Jakarta. 